(c) American Dairy Science Association, 2005.

\title{
Short Communication: Intramammary Infusion of IGF-I Increases Bromodeoxyuridine Labeling in Mammary Epithelial Cells of Prepubertal Heifers*
}

\author{
L. F. P. Silva, ${ }^{1}$ J. S. Liesman, ${ }^{2}$ B. E. Etchebarne ${ }^{2}$ M. S. Weber Nielsen, ${ }^{2}$ \\ and M. J. VandeHaar ${ }^{2}$ \\ ${ }^{1}$ Department of Animal Production and Nutrition, Faculty of Veterinary Science, \\ University of São Paulo, Brazil \\ ${ }^{2}$ Department of Animal Science, Michigan State University, East Lansing 48824
}

\begin{abstract}
When dairy heifers are fed to gain more than $900 \mathrm{~g}$ of body weight/d, they have less mammary parenchymal DNA at puberty but more insulin-like growth factor-I (IGF-I) in serum. This negative relationship between serum IGF-I concentration and mammary epithelial cell proliferation is in disagreement with the extensively reported role of IGF-I as a stimulator of mammary epithelial cell proliferation. Despite the large body of evidence suggesting that an increase in IGF-I concentration should lead to an increase in mammary epithelial cell proliferation of prepubertal heifers, it had not been previously tested. Our objective was to determine if intramammary infusions of IGF-I would stimulate mammogenesis in prepubertal heifers in vivo. After 7 $\mathrm{d}$ of treatment, bromodeoxyuridine was infused intravenously and heifers were slaughtered $3 \mathrm{~h}$ later. Samples from 3 regions of the mammary parenchyma were collected, fixed, sliced, and incubated with bromodeoxyuridine monoclonal antibody to identify cells in the Sphase of the cell cycle. Intramammary infusion of IGFI increased the percentage of epithelial cells in the Sphase by $52 \%$ ( 6.4 vs. $4.2 \%, \pm 0.3 \%$ ). Proliferation was similar in all 3 parenchymal regions, and the response to IGF-I was similar in each region. We conclude that local IGF-I increases proliferation of mammary parenchymal epithelial cells in prepubertal heifers.
\end{abstract}

(Key words: bovine, heifer, insulin-like growth factorI, mammary gland)

Abbreviation key: BrdU = bromodeoxyuridine.

Considerable effort has been made to understand the endocrine mechanisms regulating prepubertal mam-

Received December 3, 2004.

Accepted April 13, 2005.

Corresponding author: Michael J. VandeHaar; e-mail: mikevh@ pilot.msu.edu.

*This project was supported by National Research Initiative Competitive Grant no. 2003-35206-12873 from the USDA Cooperative State Research, Education, and Extension Service. mary development. One factor that is likely a major regulator of mammary ductal development is IGF-I (Kleinberg, 1998). However, although high-energy intake before puberty increases serum IGF-I, it decreases mass of mammary parenchymal tissue at puberty (Sejrsen and Purup, 1997). This presents a paradox for IGFI action on prepubertal mammary development. If IGFI is a stimulator of mammary development, one might expect that high-energy intake would increase, not decrease, the mass of mammary parenchymal tissue at puberty. Despite the evidence suggesting that IGF-I increases proliferation of bovine mammary epithelial cells in vivo before puberty, no reported studies have directly tested this hypothesis. The only reported in vivo study examining hormonal control of bovine mammary development demonstrated that infusion of IGF-I for $10 \mathrm{~d}$ to pregnant beef heifers increased dry fat-free weight of the half-udder, but did not significantly increase the amount of parenchymal DNA (Collier et al., 1993). Therefore our objective was to determine if intramammary infusion of IGF-I stimulates proliferation of mammary epithelial cells in prepubertal heifers in vivo. Bromodeoxyuridine (BrdU) labeling was used to assess cell proliferation.

Six prepubertal Holstein heifers, between 9 and 10 mo of age and weighing $217 \pm 10 \mathrm{~kg}$, were purchased and housed in individual stalls at the Beef Cattle Research Center of Michigan State University. Heifers were fed a corn silage-based diet once a day at restricted intake to achieve a BW gain of $700 \mathrm{~g} / \mathrm{d}$, according to NRC (2001). Experimental procedures were approved by the Michigan State University All-University Committee on Animal Use and Care. For 2 heifers, the front 2 quarters were infused with saline before the experiment to test infusion methods and the back 2 quarters were used in the experiment. In the remaining 4 heifers, 1 heifer in each pair was randomly selected to have the IGF-I treatment in quarters on the same side and the other heifer had IGF-I treatments in diagonal quarters. The quarters not infused with IGF-I treatment received saline. Lyophilized recombinant human IGF- 
I (GroPep Pty. Ltd., North Adelaide, Australia), which is identical to bovine IGF-I, was dissolved in $10 \mathrm{mM}$ $\mathrm{HCl}$, neutralized, and diluted in sterile, physiological saline at a concentration of $1 \mu \mathrm{g}$ of IGF-I/mL. The saline contained $1 \mathrm{mg}$ of BSA $/ \mathrm{mL}$ (Invitrogen, Carlsbad, CA). Ten micrograms of IGF-I was infused daily using a 12$\mathrm{mL}$ syringe with an intramammary infusion cannula. Solutions were infused at $0800 \mathrm{~h}$ each day. On the last day of treatment, an additional infusion was given at $2000 \mathrm{~h}$ to maximize the effect of the infused hormones on BrdU incorporation in the following morning. Heifers were slaughtered $14 \mathrm{~h}$ after the last infusion.

Two to $3 \mathrm{~h}$ before slaughter, BrdU (Sigma Chemical Co., St. Louis, MO) was injected into the jugular vein at a dose of $5 \mathrm{mg}$ of BrdU/kg of BW. Mammary glands were removed within 5 min of death and samples from 3 regions of the mammary parenchyma were collected as described in Capuco et al. (2002), and fixed in neutral buffered formalin (Sigma) for $18 \mathrm{~h}$. The dissected mammary glands were carefully examined for visual evidence of bacterial infection including abnormalities such as blood, flakes, clots, and wateriness. Fixed samples were dehydrated, embedded in paraffin, and sectioned at $6 \mu \mathrm{m}$ onto poly-L-lysine-treated slides as described in Capuco et al. (2002). Bromodeoxyuridine labeling was visualized by immunohistochemistry using the Histostain-SP kit (Zymed Laboratories Inc., San Francisco, CA) according to procedures described by Capuco et al. (2001). In each slide, 3 independent photographs were taken using the $20 \times$ objective of a DMLB microscope (Leica Microsystems Inc., Bannockburn, IL) equipped with a digital camera. The photographs were taken in active proliferative regions of the slide, on what appeared to be terminal ductal units. Total epithelial cells and BrdU-labeled epithelial cells were quantified by 2 independent evaluators blinded to the identity of the sample, with each evaluator counting an average of 3200 cells in each quarter.

Statistical analyses were done using the MIXED procedure of SAS (SAS Institute, 2000) with quarter as the unit of observation for treatment and blocked on front or rear half within heifer. Data were log-transformed to remove heterogeneity of variance, and are presented as back-transformed values. To test whether infusion design (IGF-I infused in quarters diagonal to each other or on the same side of the udder) or udder half (front vs. rear half) had an effect on treatment, an analysis was done on the results from the 4 heifers that had all 4 quarters treated. The model used for the analysis is: $\mathrm{Y}=\mu+$ design + design(heifer $)+$ treatment + half + (treatment $\times$ design $)+($ treatment $\times$ half $)+$ (heifer $\times$ treatment $\times$ design $\times$ half $)+$ residual.

Design was tested by design(heifer) and all other terms were tested by (heifer $\times$ treatment $\times$ design $x$

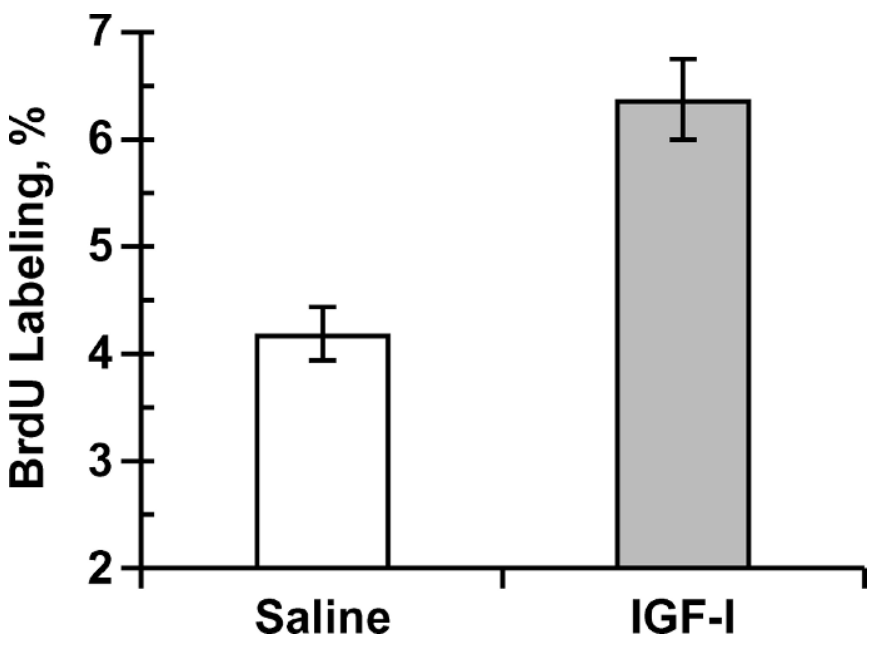

Figure 1. Effect of intramammary infusion of IGF-I on bromodeoxyuridine (BrdU) labeling of mammary epithelial cells in prepubertal heifers. Individual mammary glands of 6 heifers were infused for 7 $\mathrm{d}$ with saline or IGF-I (100 $\mu \mathrm{g} / \mathrm{d})$. Bromodeoxyuridine was infused intravenously 2 to $3 \mathrm{~h}$ before slaughter. Infusion of IGF-I increased BrdU labeling by $52 \%(P<0.001)$.

half). When it was determined that design and half did not affect treatment, the effect of IGF-I infusion was analyzed using results from all 6 heifers (total of 20 quarters) with the model: $\mathrm{Y}=\mu+$ treatment + half(heifer $)+$ (treatment $\times$ half $\times$ heifer $)+$ region + (region $\times$ treatment) + residual. Treatment (IGF-I vs. saline infusion) was tested with (treatment $\times$ half $\times$ heifer) and region and region $\times$ treatment was tested with the residual.

Intramammary infusion of IGF-I increased BrdU-labeling of mammary epithelial cells by $52 \%$ (Figure 1). The present study demonstrates for the first time that an increase in IGF-I concentration above normal accelerates the rate of mammary epithelial cell proliferation in prepubertal heifers. In vitro, IGF-I stimulates proliferation of primary bovine mammary epithelial cells, with maximum stimulation occurring at approximately 25 to $50 \mathrm{ng} / \mathrm{mL}$, a concentration much lower than that found in serum (Peri et al., 1993; Weber et al., 1999). As serum concentration of IGF-I in heifers fed moderateenergy diets is already above the maximum dose determined in cell culture studies, the lower mass of mammary parenchymal tissue of heifers when fed high-energy diets could be explained simply by a lack of response of mammary epithelial cells to an increase in IGF-I above normal concentrations. Our results demonstrate that the bovine prepubertal mammary gland is responsive to an increase in IGF-I concentrations and therefore should develop faster in high-energy fed animals with higher serum IGF-I concentration. Despite the responsiveness of the prepubertal mammary gland 
Table 1. Effect of experimental design on bromodeoxyuridine (BrdU) labeling of saline- and IGF-I-treated quarters in prepubertal heifers. Data are presented as back-transformed means from log of BrdU index.

\begin{tabular}{llllll}
\hline & \multicolumn{2}{c}{ Design $^{1}$} & & \multicolumn{2}{c}{ Half $^{2}$} \\
\cline { 2 - 3 } & Diagonal & Same-side & & Front & Rear \\
\hline Saline, \% & 3.4 & 5.1 & & 4.6 & 3.8 \\
IGF-I, \% & 5.8 & 6.8 & & 6.3 & 6.2 \\
Response to IGF-I & 1.69 & 1.32 & & 1.36 & 1.63 \\
\hline
\end{tabular}

${ }^{1}$ Design describes whether IGF-I was infused in quarters diagonal to each other or on the same side of the udder. There was no effect of experimental design on treatment responses ( $P$ value of treatment $\times$ design $=0.26$.

${ }^{2}$ Half describes either the front or the rear quarters of the udder. There was no effect of half of the udder on treatment responses $(P$ value of treatment $\times$ half $=0.41$ ).

${ }^{3}$ Response to IGF-I was calculated as BrdU-labeling in IGF-Itreated quarters divided by BrdU-labeling in control quarters.

to IGF-I, mammary development is impaired when heifers receive high-energy diets. Therefore, serum IGF-I concentration is not the only factor regulating prepubertal mammogenesis. This other factor could be one or all of the IGF-binding proteins, or some other molecule.

To use the in vivo model developed here to test for hormonal effects on mammogenesis, it is necessary to test for independence of mammary quarters. To consider each quarter of the udder as a separate experimental unit, the treatment infused in 1 quarter cannot influence the result obtained in another quarter. Infusion of IGF-I in diagonal quarters gave a similar response as infusion of IGF-I in quarters of the same side $(P=0.26$, Table 1$)$, indicating that there was no significant translocation of IGF-I to same-lateral quarters and therefore each quarter could serve as a separate experimental unit. If the mammary quarters are indeed independent, as suggested by our results, this would allow 2 comparisons to be made in each animal, reducing by half the number of animals needed for mammary biology studies when compared with the more traditional hemiudder approach. In addition, more than 1 treatment could be tested in the same animal. There also was no difference in BrdU incorporation in front or rear udder halves $(P=0.41$, Table 1$)$.

Proliferation as indicated by BrdU-labeling was similar among the 3 parenchymal regions in control quarters (Figure 2). Proliferation at the region distal from the teat was not different $(P=0.64)$ than proliferation at the proximal region. The response to IGF-I was also similar $(P=0.78)$ among regions (Figure 2$)$.

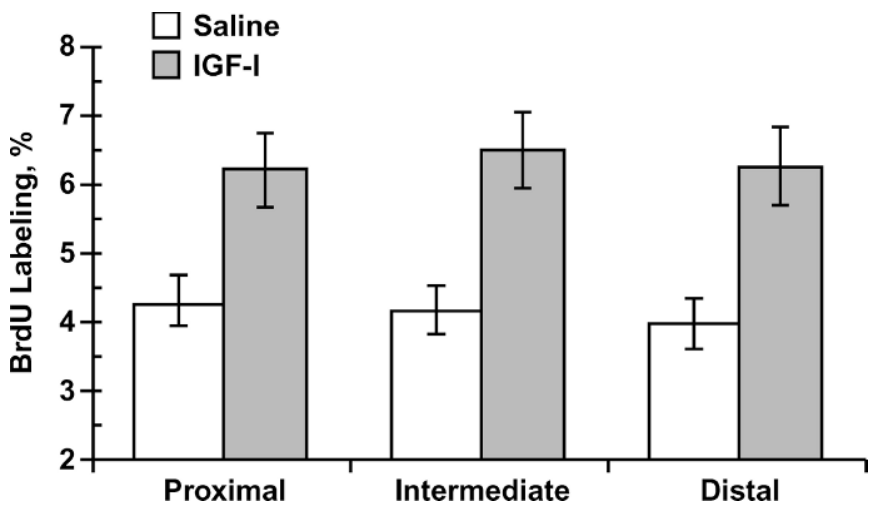

Figure 2. Bromodeoxyuridine (BrdU) labeling in 3 parenchymal regions of individual mammary glands infused with either saline of IGF-I. Proliferation in both saline- and IGF-I-treated quarters was similar among the 3 parenchymal regions tested $(P>0.6)$. The response to IGF-I was also similar among regions $(P=0.78)$.

In conclusion, increasing the local concentration of IGF-I stimulates proliferation of mammary epithelial cells in prepubertal heifers. Moreover, combining intramammary infusion with the BrdU-labeling technique is a sensitive method for measuring effects of metabolic compounds on mammogenesis.

\section{REFERENCES}

Capuco, A. V., D. L. Wood, R. Baldwin, K. McLeod, and M. J. Paape. 2001. Mammary cell number, proliferation, and apoptosis during a bovine lactation: Relation to milk production and effect of bST. J. Dairy Sci. 84:2177-2187.

Capuco, A. V., S. Ellis, D. L. Wood, R. M. Akers, and W. Garrett. 2002. Postnatal mammary ductal growth: Three-dimension imaging of cell proliferation, effects of estrogen treatment, and expression of steroid receptors in prepubertal calves. Tissue Cell 34:143-154.

Collier, R. J., M. F. McGrath, J. C. Byatt, and L. L. Zurfluh. 1993. Regulation of bovine mammary growth by peptide hormones: Involvement of receptors, growth factors and binding proteins. Livest. Prod. Sci. 35:21-33.

Kleinberg, D. L. 1998. Role of IGF-I in normal mammary development. Breast Cancer Res. Treat. 47:201-208.

National Research Council. 2001. Nutrient Requirements of Dairy Cattle. 7th ed. National Academy Press, Washington, DC.

Peri, I., A. Gertler, I. Bruckental, and H. Barash. 1993. The effect of manipulation in energy allowance during the rearing period of heifers on hormone concentrations and milk production in firstlactation cows. J. Dairy Sci. 76:742-751.

SAS Institute. 2000. SAS/STAT User's guide: Version 8. SAS Inst., Inc., Cary, NC.

Sejrsen, K., and S. Purup. 1997. Influence of prepubertal feeding level on milk yield potential of dairy heifers: A review. J. Anim. Sci. 75:828-835.

Weber, M. S., S. Purup, M. Vestergaard, S. E. Ellis, J. ScndergardAndersen, R. M. Akers, and K. Sejrsen. 1999. Contribution of insulin-like growth factor (IGF)-I and IGF-binding protein-3 to mitogenic activity in bovine mammary extracts and serum. J. Endocrinol. 161:365-373. 